\title{
THE EFFECT OF DISCRETIONARY ACCRUALS ON FIRM GROWTH. EMPIRICAL EVIDENCE FOR SMES FROM EMERGING EUROPE
}

\author{
Sorin Gabriel ANTON ${ }^{(1)}{ }^{*}$, Mihai CARP (D)2 \\ ${ }^{1}$ Finance, Money, and Public Administration Department, Faculty of Economics \\ and Business Administration, Alexandru Ioan Cuza University of Iasi, Iasi, Romania \\ ${ }^{2}$ Accounting, Information Systems and Statistics Department, Faculty of Economics \\ and Business Administration, Alexandru Ioan Cuza University of Iasi, Iasi, Romania
}

Received 28 April 2019; accepted 02 March 2020

\begin{abstract}
The aim of the paper is to assess the effect of discretionary accruals on firm growth while controlling for firm characteristics and macroeconomic environment. Employing a large sample of 1.105 young and high-growth firms (gazelles) from 15 emerging European countries over the period 2006-2014, it has been found that the discretionary accruals negatively influence firm growth. The empirical results suggest that discretionary accruals are used as earnings management tools and this practice is more used over the high-growth period (2006-2009), with negative effects on future performance. Furthermore, the results of the quantile regression employed in the whole period suggest that the earnings management practices have a negative effect on firm growth. The results prove to be robust for different estimation approaches and different sub-samples of gazelles. The findings provide empirical evidence for the need for more detailed information provided by firms on the origin of the accruals, as well as for the use in the performance analysis of some indicators that eliminate the influence of accruals, such as cash flow based ratios.
\end{abstract}

Keywords: firm growth, discretionary accruals, gazelles, emerging Europe, quantile regression, earnings management, private firms, macroeconomic environment.

JEL Classifications: L25, L26, M41.

\section{Introduction}

The quality of financial information reported by firms and their influence on the decisions of different users are widely discussed in the literature. Identified as accounting adjustments that explain the differences between the accrual accounting principles and cash accounting principles (Walker, 2013), accruals represent a benchmark in assessing the earnings quality. These are generated both by the application of strict accounting rules and by the use of professional judgment (options in choosing accounting treatments). Starting from these sources of occur-

${ }^{\star}$ Corresponding author. E-mail: sorin.anton@uaic.ro 
rence, the separation of accruals into discretionary (DAC) and non-discretionary accruals (NDAC) is often a difficult task (Dechow et al., 2012), but necessary in assessing managers' behavior in using these elements which do not involve repayment (do not change cash flows) but influence the level of financial results (Tsipouridou \& Spathis, 2012). The DAC dimension, as a result of the application of the accounting choice, is predominantly associated with the opportunistic and manipulator behavior of managers (Kuo et al., 2014) with the purpose of sizing the results according to their own objectives (Abernathy et al., 2014). However, DAC is a tool that, ethically used, can help increase the value of the firm (Omar et al., 2014), managers choosing the most favorable accounting treatments and reporting methods, thereby influencing how economic events are reflected in the performance indicators (Walker, 2013).

A small number of studies identify the positive role of DAC in signaling future performance (Robin \& Wu, 2015; Dechow et al., 2019; Darmawan et al., 2019; Chen \& Gong, 2019). These studies focus in particular on the impact of DAC on investor decisions, by reference to the stock market. Thus, the segment of non-listed companies, respectively the perspective of other users of financial information (banks, business partners), who can influence by their own perception the firm growth, is neglected. This paper focuses on this segment of unlisted companies with significant growth, covering a gap in the research into the relationship between the magnitude of DAC and firm growth. Furthermore, the paper analyzes a sample of young high-growth firms from a region characterized by a poor investor protection.

The aim of the paper is to study the effect of discretional accruals on firm growth on a sample of highly desired SMEs, namely young and high-growth firms (so-called "gazelles") from emerging Europe for the period 2006-2014 ${ }^{1}$. The special focus on gazelles is motivated by the important role these firms play in the transition economies for job creation, innovation, and economic development (Anton, 2019). Secondly, as the problems of information asymmetry and agency costs are more pronounced in the case of young and high-growth firms, managers are more likely to use indirect mechanisms (such as accruals) rather than direct mechanisms (press releases and conference calls) in signaling future favorable performance (Robin \& Wu, 2015). Thirdly, these samples of firms allow us to study the impact of discretionary accruals over the period of high-growth and also after the high-growth period. Fourthly, young and high-growth firms are interesting to study as they are more likely to commit fraud (Vladu et al., 2017) due to the poor investor protection. Thus, these results are of interest for managers, entrepreneurs, investors, and policymakers.

The empirical findings show that discretionary accruals have a negative influence on firm growth, which reflects their use as a tool for earnings management through accounting choice. The negative relationship is more pronounced over the high-growth period (20062009) and it hampers future growth. The effects are also confirmed by the results of the quantile regression employed for the whole period (2006-2014), the magnitude of the relationship being higher in the case of low-growth firms. The paper contributes to the extant literature in several ways. Firstly, it provides empirical evidence on the effect of discretionary accru-

\footnotetext{
${ }^{1}$ In this paper we use the definitions provided by Eurostat-OECD for high-growth firms and gazelles. HGFs represent "all enterprises with average annualized growth greater than $20 \%$ per annum, over a three year period.... Growth can be measure by the number of employees or by turnover" (Eurostat-OECD, 2007, p. 61), while gazelles are "the subset of high-growth enterprises which are up to five years old" (Eurostat-OECD, 2007, p. 63).
} 
als on firm growth using a sample of private firms located in emerging market economies. Secondly, unlike previous studies which have focused mainly on samples located in one country or one industry, it is the first study that deals with a cross-country sample. Thirdly, to the best of authors' knowledge, this is the first study employing a sample of gazelles. Fourthly, the current analysis comprises a long and recent period of time, comprising both economic growth and downturn captured by the macroeconomic variables in the econometric estimations. Fifthly, the paper extends previous studies in terms of the methodology employed for testing the linkage between discretionary accruals and firm growth by using the quantile regression.

The remainder of this paper is organized as follows. Section 1 provides a concise literature review of the effect of accruals on firm growth and summarizes the research hypothesis. Section 2 describes the data, the variables, and the methodology employed in the paper. Section 3 presents the main empirical results and robustness checks. The last section concludes.

\section{Literature review}

Accruals and their components represent a highly discussed topic in the literature, due to their impact on the indicators computed on the basis of the financial information reported by the firms, respectively on the corresponding decisions adopted by the investors. According to signal theory, managers can use accruals as private communication tools related to the entity's future performance (Koerniadi \& Tourani-Rad, 2011).

If non-discretionary accruals are identified as items resulting from the application of fundamental accounting rules that cannot be changed by managers, discretionary accruals derive from accounting choices, managerial decisions, and various estimates (Francis et al., 2005). Although the role of discretionary accruals in the elaboration and publication of financial information is still widely debated, two different interpretations emerged in the extant literature.

Treated in a limited way in the literature, the presence of DAC can be interpreted as a positive action tool that reflects the ability of managers to identify the most efficient ways to use resources employed in the operational activity, concurrent with using of the optimal accounting treatments to reflect the financial performance. In this regard, Francis et al. (2005) identify the possibility of interpreting DAC as performance indicators, reflecting the managers' option to publish credible and timely results in order to reduce information risk. Accruals and firm growth are fundamentally correlated (Collins et al., 2016) and discretionary accruals can exert a positive signal effect (Pham et al., 2017) to reduce information asymmetries.

In the second interpretation, the DAC dimension is predominantly associated with the level of opportunistic behavior of managers, conducted in order to manipulate the results and which leads to the reduction of the quality of financial information (Jones, 1991; Teoh et al., 1998; Zéghal et al., 2011; Pelucio-Grecco et al., 2014; Arun et al., 2015; Lo et al., 2017; Rodrigues et al., 2019). Defined as earnings management, these practices can alter the information published by companies by changing accounting treatments or valuation methods (Zang, 2012) or by using specific transaction-handling actions to mislead stakeholders about the level of performance achieved, with consequences on the contractual benefits dependent on the published accounting data (Healy \& Wahlen, 1999). The manipulation of discretionary 
accruals has as main aim "borrowing" some results from future periods or "postponing" current ones for a future moment (Abernathy et al., 2014), all with the purpose of opportunistic control of the level of performance (Perotti \& Wagenhofer, 2014). In order to meet these self-imposed objectives, managers can intervene by manipulating sales (offering short-term discounts to increase sales, relaxing sales credit conditions), or generating overproduction (to reduce production costs) (Ge \& Kim, 2014).

The bi-directional relationship between accruals and firm performance has been extensively studied in the literature. However, this relationship is treated predominantly unilateral in the empirical literature, from the perspective of the contribution of firm performance measured by various indicators such as sales growth (Doukakis, 2014; Collins et al., 2016; Lehmann, 2016), book-to-market ratio (Filip \& Raffournier, 2014) or profitability (Karampinis \& Hevas 2013; Filip et al., 2015; Owens et al., 2016) ${ }^{2}$ - on the level of accruals.

A less explored dimension of this relationship is represented by the effect of accruals on firm performance. This relationship has the potential to reflect the role of managerial decisions on firm performance. Discretionary accruals may transmit a negative signal to the market, and investors may penalize the firm because they perceive larger accruals as opportunistic behaviors. Momente, Reggiani, and Richardson (2015) analyze the relationship between accruals and future performance of U.S. - listed companies dividing accruals into firm-related components, respectively generated by external factors. They find a negative association between the two types of accruals and performance, largely due to internal factors. However, the size of the DAC, which could more specifically identify the effect of the managerial decisions which generates accruals, is not involved in their analysis. Kuo et al. (2014) identify a positive relationship between discretionary accruals and sales growth for Chinese listed companies and interpret the phenomenon as a swift in the earnings activities from accrual-based earnings management to real-based earnings management after the split share structure reform. However, the relevance of their conclusions is limited due to the use of information from a single economy and in the light of the specific economic reforms. Other studies employed accruals, along with a series of firm growth indicators, in the market price formation analysis and their recognition as factors of influence (Jenkins \& Velury, 2012; Robin \& Wu, 2015). Pham et al. (2017) study the role of discretionary accruals as performance signals or earnings management tool and show the positive effect of DAC growth on stock return, especially for fast-growing firms. Testing the robustness of the models developed on this subject involved a number of control variables, predominantly specific to the firm, such as the size (Habib, 2013), leverage (Datta et al., 2013), the reputation of the auditor (Gavious et al., 2012) or the quality of corporate governance (Sun et al., 2010; Pham et al., 2017), but without including the role of macroeconomic factors whose presence is absolutely necessary.

Studies on the effect of discretionary accruals on the entity's performance focus mainly on listed companies in different stock markets and on the investors' reaction. Relatively neglected

\footnotetext{
$\overline{2}$ Sales growth is one of the most used proxies for firm growth (Collins et al., 2016), as it is a relatively robust indicator that is not significantly affected by the influence of alternative accounting treatments. From the perspective of the efficiency of the activity, the firm performance is reflected by the evolution of indicators such as ROA (return on assets), the book-to-market ratio (Momente et al., 2015), return on equity or market value.
} 
is the segment of non-listed companies, where financial information generally addresses other categories of users (banks, business partners) that can influence the firm growth by their own behavior. In the case of listed companies, users of published financial information benefit from different protection mechanisms, including listing requirements or financial statement auditing services, which ensure a high-quality level of published results (Haga et al., 2018). In the case of unlisted companies, the lack of such quality assurance mechanisms makes financial reporting play a lesser role in communicating with external users (Beuselinck et al., 2009), thus lowering the quality of the results (Chen et al., 2011). Under these circumstances, managers can use more easily earnings management techniques. Thus, it is necessary to study the influence of the DAC on sales growth, which complements the individual analyzes of users (business partners, banks, potential investors) of financial information published by relatively opaque entities.

Also, a few studies focused on the quality of information published by SMEs (Szczesny \& Valentincic, 2013; Gao et al., 2015), respectively on SMEs from emerging Europe (Vafeas et al., 1998). The need to study the role of the DAC on SMEs' growth derives from the specificities of actions they need to take to penetrate a market dominated by large firms. They can use innovative marketing strategies or measures to improve the efficiency of their activity, as well as earnings management actions, precisely to overcome this stage of their own evolution, or to show increased performance, respectively, a better image that will facilitate their access to finance (Chen et al., 2011; Campa, 2015) or even increasing market share. In the emerging markets economies, there are additional motivations for reducing the quality of results (through earnings management), due to poor investor protection, bank-oriented financial systems, and the tight link between tax and accounting treatments (Chen et al., 2011). The use of earnings management reduces the usefulness of reported financial information (Perotti \& Wagenhofer, 2014), causing unfavorable effects on the future performance of companies (Fischer \& Rosenzweig, 1995). A particular set of SMEs is represented by young and fast-growing firms (so-called gazelles) which have a significant contribution to economic development despite their low number. These firms have the highest motivation to use earnings management in order to signal fast growth.

In order to identify whether and how these firms use the DAC as part of the financial information communication strategies and the effect on the company's growth, the study analyzes the aforementioned relationship both during and after the high-growth period.

Starting from the elements identified in the literature, the paper proposes to test the following research hypothesis:

H1: There is a negative relationship between discretionary accruals and firm growth.

\section{Data and methodology}

\subsection{Sample}

The sample of firms is selected according the Eurostat-OECD' definitions proposed in the Manual on Business Demography Statistics (Eurostat-OECD, 2007). Thus, the following criteria have been employed: (1) firms should have 10 or more employees in the starting year (2006) and an average annualized growth rate higher than $20 \%$ in a 3 -year period (2006-2009); (2) at the end of the 3-year time period, the age of the firms should be less than five years (Eurostat-OECD, 2007). The initial sample consists of 1,163 gazelles over the 
period 2006-2014. In the second step, usually cleaning procedures have been applied and, as a result, the final sample consists of 1,105 gazelles and 9,804 firm-year observations ${ }^{3}$ over a 9-year period (2006-2014) from 15 Central, Eastern, and South-Eastern European (CESEE) countries $^{4}$. This longer period of time (comprising both crisis and recovery period) allow us to draw lessons usefull nowadays when International Monetary Fund (IMF) identified increased uncertainty in emerging economies (International Monetary Fund, 2020). To control for the potential influence of outliers, all firm-level data are winsorized at the $1 \%$ level.

All firm-level data have been retrieved from Amadeus, while cross-country data on economic growth and economic development have been downloaded from World Development Indicators (World Bank, 2016).

Sales growth, the dependent variable, is measured as the logarithmic difference in sales in two consecutive years in line with prior studies (e.g., Miroshnychenko et al., 2018). This indicator is considered a proxy for product/service acceptance in the market (Anton, 2019) and also the most suitable measure of growth as it captures both short- and long-term performance (Davidsson \& Wiklund, 2006).

Table 1. Variables description

\begin{tabular}{|l|l|l|}
\hline \multicolumn{1}{|c|}{ Variable } & Abbreviation & \multicolumn{1}{c|}{ Description } \\
\hline Sales growth & SALESGR & Log $\left(\right.$ sales $\left._{\mathrm{i}, \mathrm{t}}\right)-\log \left(\mathrm{sales}_{\mathrm{i}, \mathrm{t}-\mathrm{1}}\right)$ \\
\hline Discretionary accruals & DAC & Residual variables (error term) from Jones (1991) model \\
\hline $\begin{array}{l}\text { Non-discretionary } \\
\text { accruals }\end{array}$ & NDAC & Total accruals - discretionary accruals \\
\hline Firm size & SIZE & Log of total assets \\
\hline Firm age & AGE & Log of firm age \\
\hline Labor productivity & LP & Log of total sales/number of employees \\
\hline Debt ratio & DR & (Non-current liabilities + Loans)/Total assets \\
\hline Economic growth & ECGR & GDP growth (annual \%) \\
\hline Economic development & ECDEV & Log of GDP per capita (current US\$) \\
\hline
\end{tabular}

The size of the accruals can be estimated by the means of two methods. In this respect, starting from the effects of applying accrual accounting, respectively those specific of cash accounting, total accruals represent the difference between net income (NI) and operating cash flow (OCF). The second way of estimation used in this paper identifies total accruals (TA) by involving some structures in the financial statements (Pelucio-Grecco et al., 2014), according to Eq. (1):

$$
T A_{t}=\left[\left(\Delta C A_{t}-\Delta \operatorname{Cash}_{t}\right)-\left(\Delta C L_{t}-\Delta S T D_{t}\right)\right]-D E P_{t},
$$

\footnotetext{
${ }^{3}$ However, given the high number of missing values for some variables employed in the calculation of total accruals, the number of the observations for the growth and post-growth period for our unbalanced data panel is much lower.

${ }^{4}$ Bosnia and Herzegovina, Bulgaria, Croatia, Czech Republic, Estonia, Hungary, Latvia, Lithuania, Macedonia, Poland, Romania, Serbia, Slovak Republic, Slovenia, and Ukraine.
} 
where: $T A_{t}$ - total accruals in year $t ; \Delta C A_{t}$ - change in the current assets in year $t$ from year $t-1 ; \Delta$ Cash $_{t}$ - change in cash \& short-term investments in year $t$ from year $t-1$; $\Delta C L_{t}$ - change in the current liabilities in year $t$ from year $t-1 ; \Delta S T D_{t}$ - change in the short term debts in year $t$ from year $t-1 ; D E P_{t}$ - depreciation and amortization in year $t$.

To separate the two components of accruals (discretionary and non-discretionary), the econometric model proposed by Jones (1991) was employed (Eq. (2)). This approach has been extensively employed in the extant literature (Kuo et al., 2014; Heese, 2018). DAC is the residual component of the equation, i.e. the unexplained part of TA variation through independent variables.

$$
\frac{T A_{t}}{A T_{t-1}}=\beta_{0} \frac{1}{A T_{t-1}}+\beta_{1} \frac{\Delta R E V_{t}}{A T_{t-1}}+\beta_{2} \frac{P P E_{t}}{A T_{T-1}}+\varepsilon,
$$

where: $T A_{t}$ - total accruals in year $t ; A T_{t-1}$ - total assets in year $t-1 ; \triangle R E V_{t}$ - change in revenues in year $t$ from year $t-1 ; P P E_{t}$ - gross property, plant, and equipment in year $t ; \varepsilon-$ error term, the discretionary accruals (DAC).

According to the model developed by Jones (1991), NDAC is the difference between total accruals and discretionary accruals as expressed by the relationship no. 3 .

$$
N D A C=T A-D A \text {. }
$$

All three variables TA, NDAC and DAC are deflated to total assets at the beginning of the period.

In line with the relevant literature on firm growth (e.g. Rahaman, 2011), the study employs as control variables the following traditional firm characteristics: firm size, firm age, labor productivity, and debt ratio. A description of these variables is provided in Table 1. All nominal values are deflated by countries' GDP deflators provided by the World Bank.

Several papers (Miroshnychenko et al., 2018) show that the macroeconomic environment affects sales growth. Annual GDP growth and GDP per capita are included to account for cross-country difference in economic growth and development. In addition, year dummies are used as control variables in all regressions to control heterogeneity over time.

\subsection{Econometric specifications and methods}

The following linear regression model for panel data is considered:

$$
\begin{aligned}
& \text { SALESGR }_{i, j, t}=\alpha_{i, j}+\beta_{1} D A C_{i, j, t-1}+\beta_{2} N D A C_{i, j, t-1}+ \\
& \beta_{3} \text { FIRM }_{-} L E V_{i, j, t}+\beta_{4} M A C R O \_L E V_{j t}+\varepsilon_{i, j, t},
\end{aligned}
$$

where: SALESGR ${ }_{i, j}, t$ denotes growth of firm $i$, in country $j$, at time $t$ computed as the logarithmic difference in sales in two consecutive years; $D A C_{i, j, t-1}$, our independent variables of interest, measures the value of discretionary accruals for firm $i$, in country $j$, at time $t-1$; $N D A C_{i, j, t-1}$ measures the value of non-discretionary accruals for firm $i$, in country $j$, at time $t-1$; the vector FIRM_LEV ${ }_{i, j}, t$ includes firm-specific variables, namely firm size, age, degree of indebtedness, and labor productivity; the vector $M A C R O \_L E V_{j, t}$ captures macroeconomic variables such as economic growth and economic development for country $j$ at time $t ; \alpha_{i, j}$ are firm-specific fixed effects; $\beta_{1}, \ldots, \beta_{4}$ are parameters to be estimated; $\varepsilon_{i, j, t}$ is an error term 
capturing all factors that influence firm growth, but are not included in the model specification's variables. Following Sial, Zheng, Khuong, Khan, and Usman (2018), DAC and NDAC are lagged 1 year in order to clarify the causality relationship.

Four different methods have been employed in order to estimate the model specification (Eq. (4)). Firstly, the paper employed a pooled ordinary least-squares regression model (OLS) with robust standard errors in order to obtain heteroskedasticity-robust estimators. Secondly, a panel fixed effects model (FE) is employed. As suggested by Hsiao (2003), the Hausman test is used to determine the exogeneity of the unobserved errors and to choose between fixed-effects and random-effects models. The test rejects the random-effects specification to all model specifications, so FE estimations are adopted. The third method, OLS with Panelcorrected Standard Errors (PCSE), controls for firm-level heteroscedasticity and provides more robust results. Fourthly, quantile regression is employed in order to test whether the impact of accruals can be different for various levels of firm growth. Also, this approach mitigates the problem of non-Gaussian error distribution. The quantile regression model originally proposed by Koenker and Bassett (1978) has the following specification:

with

$$
y_{i, t}=x_{i, t}^{\prime} \beta_{0}+\varepsilon_{i, t},
$$

$$
\operatorname{Quant}_{\theta}\left(y_{i, t} \mid x_{i, t}\right)=x_{i, t}^{\prime} \beta_{0},
$$

where $y_{i t}$ represent the dependent variable (sales growth), $x_{i t}$ represent a vector of regressors, $\beta$ is the vector of parameters to be estimated, $\varepsilon$ is a vector of residuals, $i$ denotes firm and $t$ denotes time. Quant ${ }_{\theta}\left(y_{i t} \mid x_{i t}\right)$ denotes the $\theta^{\text {th }}$ conditional quantile of $y_{i t}$ given $x_{i t}$. All the econometric estimates have been carried out using the econometric software STATA 14.

\section{Empirical results and discussion}

\subsection{Descriptive statistics and correlation}

Table 2 reports the descriptive statistics for the variables used in the estimations for the high-growth period (2006-2009), for after the high-growth period (2010-2014) and for the whole period (2006-2014), useful both for the knowledge of the economic and financial environment in which the phenomenon is analyzed and for the characterization of the data series distribution.

The high value of the average growth rate of turnover $(11.75 \%)$ for the analyzed period confirms the features of the entities included in the study, namely HGFs. However, there are significant differences over the three periods. Over the high-growth period, the average sales growth rate is $41.96 \%$, while over the post-high-growth period, the average sales growth is negative $(7.46 \%)$.

At the level of the entire sample, the NDAC represents, in absolute terms, an average of $3.12 \%$ of the total assets of the previous year, with a normal distribution around the average. DAC records absolute average values similar to NDAC (3.31\%), but with a significant dispersion around the average, which shows the diversity of solutions used for accounting registration of events and transactions. However, there is a significant difference between DAC values within the two growth intervals analyzed. Over the high-growth period, the level of DAC $(-0.05488)$ is higher than the value recorded for the post-high-growth period 
$(-0.01747)$, highlighting the intensive use of accounting choice in case of gazelles with possible influences on the result indicators. The average values of DAC and NDAC are in line with those reported by Jenkins and Velury (2012) and Pham et al. (2017).

Table 2. Summary statistics

\begin{tabular}{|c|c|c|c|c|}
\hline Variable & Mean & Std. Dev. & Min & Max \\
\hline \multicolumn{5}{|c|}{ High-growth period (2006-2009) } \\
\hline SALESGR & 0.419691 & 0.922055 & -6.23841 & 8.893155 \\
\hline DAC & -0.05488 & 0.946495 & -2.84977 & 2.894756 \\
\hline NDAC & -0.01827 & 0.504327 & -1.48673 & 1.758118 \\
\hline SIZE & 13.561 & 2.020991 & 5.342545 & 20.15283 \\
\hline AGE & 0.976431 & 0.489942 & 0 & 1.609438 \\
\hline LP & 10.31347 & 1.531754 & 2.592976 & 16.74459 \\
\hline $\mathrm{DR}$ & 0.231338 & 0.311605 & 0 & 1.662131 \\
\hline ECGR & 2.663416 & 7.20798 & -14.8142 & 11.90219 \\
\hline ECDEV & 8.849895 & 0.667158 & 7.741976 & 10.22201 \\
\hline \multicolumn{5}{|c|}{ Post high-growth period (2010-2014) } \\
\hline SALESGR & -0.07467 & 0.770673 & -9.13022 & 5.360777 \\
\hline DAC & -0.01747 & 0.506575 & -2.84977 & 2.894756 \\
\hline NDAC & -0.03996 & 0.295572 & -1.48673 & 1.758118 \\
\hline SIZE & 14.16199 & 2.11932 & 1.932333 & 20.78376 \\
\hline AGE & 1.963935 & 0.226268 & 1.386294 & 2.302585 \\
\hline LP & 10.43292 & 1.376255 & 3.599059 & 16.93404 \\
\hline $\mathrm{DR}$ & 0.232964 & 0.316235 & 0 & 1.662131 \\
\hline ECGR & 1.26162 & 2.583426 & -6.6 & 7.583125 \\
\hline ECDEV & 8.991573 & 0.61111 & 7.997662 & 10.12598 \\
\hline \multicolumn{5}{|c|}{ Full period (2006-2014) } \\
\hline SALESGR & 0.117591 & 0.866944 & -9.13022 & 8.893155 \\
\hline DAC & -0.03318 & 0.724858 & -2.84977 & 2.894756 \\
\hline NDAC & -0.03121 & 0.393464 & -1.48673 & 1.758118 \\
\hline SIZE & 13.89025 & 2.096776 & 1.932333 & 20.78376 \\
\hline AGE & 1.523736 & 0.613442 & 0 & 2.302585 \\
\hline LP & 10.37729 & 1.451887 & 2.592976 & 16.93404 \\
\hline $\mathrm{DR}$ & 0.232236 & 0.314149 & 0 & 1.662131 \\
\hline ECGR & 1.899021 & 5.267592 & -14.8142 & 11.90219 \\
\hline ECDEV & 8.927152 & 0.641068 & 7.741976 & 10.22201 \\
\hline
\end{tabular}


Table 3. Correlation matrix

\begin{tabular}{|l|c|c|c|c|c|c|c|c|c|}
\hline & SALESGR & DAC & NDAC & SIZE & AGE & LP & DR & ECGR & ECDEV \\
\hline SALESGR & 1 & & & & & & & & \\
\hline DAC & -0.2175 & 1 & & & & & & & \\
\hline NDAC & 0.0471 & -0.1664 & 1 & & & & & & \\
\hline SIZE & 0.0319 & 0.1773 & 0.0635 & 1 & & & & & \\
\hline AGE & -0.3626 & 0.0886 & -0.0438 & 0.2109 & 1 & & & & \\
\hline LP & 0.1548 & -0.1394 & 0.0654 & 0.5305 & 0.066 & 1 & & & \\
\hline DR & 0.0177 & 0.1826 & 0.0877 & 0.2031 & 0.003 & -0.0053 & 1 & & \\
\hline ECGR & 0.1835 & -0.0174 & 0.0376 & 0.0108 & -0.2278 & 0.1327 & -0.0074 & 1 & \\
\hline ECDEV & -0.0937 & 0.0597 & 0.0019 & 0.0907 & 0.1763 & 0.3159 & -0.0838 & 0.1741 & 1 \\
\hline
\end{tabular}

Table 3 presents correlations among the dependent and independent variables. The results suggest a negative correlation between the level of discretionary accruals and sales growth. On the other hand, the correlation between non-discretionary accruals and sales growth is positive but weak. There are also low correlation coefficients between the independent variables which suggest that multicollinearity is unlikely to be a problem in our panel data analysis.

\subsection{Empirical results}

The empirical results for the high-growth period (2006-2009) are presented in Table 4. The analysis developed in order to identify the effects of discretionary accruals on firm growth generated a series of information synthesized in Table 4. The results do not reject the research hypothesis and reveal a negative influence of discretionary accruals on firm growth, meaning that managerial decisions generating accruals are interpreted in the case of HGFs as an instrument of erosion of their performance. The regression coefficients attached to the DAC variable are negative for all three models estimated, being statistically significant at the $1 \%$ level. Thus, a possible interpretation of the DAC as a tool for earnings management is identified in the case of HGFs, similar to some interpretations of Wilson and Wang (2010), Capalbo, Frino, Mollica, and Palumbo (2014), respectively Ben Amar, Ben Salah, and Jarboui (2018). The results confirm a series of findings of Pham et al. (2017) but opposed to those reported by Jenkins and Velury (2012) and Robin and $\mathrm{Wu}$ (2015) on the impact of the DAC on growth measured by the entity's stock market performance. By reference to the growth of the entity measured by fundamental indicators (sales growth, ROA), our results are opposite to those reported by Robin and $\mathrm{Wu}$ (2015) (on the growth of ROA) and Koerniadi and Tourani-Rad (2011) (sales growth). Thus, our results confirm the existence of particular influences on the gazelles' operational activity due in particular to the elements of the discretionary accruals (gazelles can choose strategies that determine a high level of working capital and accounting treatments to increase the accounting result). 
Table 4. Empirical results for the high-growth period (2006-2009)

\begin{tabular}{|c|c|c|c|}
\hline & Model 1 & Model 2 & Model 3 \\
\hline & OLS & $\mathrm{FE}$ & PCSE \\
\hline \multirow{2}{*}{ DAC } & $-0.2540^{\star \star \star}$ & $-0.3202^{\star \star \star}$ & $-0.2670^{\star \star \star}$ \\
\hline & $(-0.0441)$ & $(-0.0536)$ & $(-0.0391)$ \\
\hline \multirow{2}{*}{ NDAC } & -0.0265 & 0.0075 & -0.0169 \\
\hline & $(-0.0701)$ & $(-0.0619)$ & $(-0.0567)$ \\
\hline \multirow{2}{*}{ SIZE } & $0.0619^{\star * *}$ & 0.0463 & $0.0496^{*}$ \\
\hline & $(-0.0215)$ & $(-0.0859)$ & $(-0.0294)$ \\
\hline \multirow{2}{*}{ AGE } & $-0.6500^{\star * *}$ & $-2.2606^{\star * *}$ & $-0.6967^{\star * *}$ \\
\hline & $(-0.0981)$ & $(-0.3519)$ & $(-0.0983)$ \\
\hline \multirow{2}{*}{ LP } & 0.0269 & $0.7194^{* * *}$ & 0.0649 \\
\hline & $(-0.0417)$ & $(-0.1008)$ & $(-0.0488)$ \\
\hline \multirow{2}{*}{ DR } & $0.2529^{\star * \star}$ & 0.1534 & $0.2497^{\star *}$ \\
\hline & $(-0.0835)$ & $(-0.1722)$ & $(-0.1113)$ \\
\hline \multirow{2}{*}{ ECGR } & $0.0093^{*}$ & $0.0442^{\star * *}$ & 0.0101 \\
\hline & $(-0.0054)$ & $(-0.012)$ & $(-0.0068)$ \\
\hline \multirow{2}{*}{ ECDEV } & $-0.1497^{\star \star *}$ & $-1.2510^{\star * *}$ & $-0.1723^{\star \star *}$ \\
\hline & $(-0.0371)$ & $(-0.4269)$ & $(-0.0357)$ \\
\hline \multirow{2}{*}{ Constant } & $1.2668^{\star * *}$ & 4.8091 & $1.2585^{* * *}$ \\
\hline & $(-0.3171)$ & $(-4.035)$ & $(-0.3292)$ \\
\hline Time FE & Yes & Yes & Yes \\
\hline Industry FE & Yes & Yes & Yes \\
\hline Observations & 1799 & 1799 & 1799 \\
\hline R-squared & 0.1823 & 0.1003 & 0.1946 \\
\hline
\end{tabular}

Note: Robust standard errors are reported in brackets and account for clustering at the firm level. ${ }^{* *}$, ${ }^{*}$, and ${ }^{*}$ denote statistical significance at the $1 \%, 5 \%$, and $10 \%$ levels, respectively.

Non-discretionary accruals, an exponent of the application of treatments strictly regulated by the accrual accounting principles, do not have a significant influence on the firm's growth, being interpreted as a compliance with the rules in the field without significant impact on the size of the performance indicators, similar to evidence provided by Koerniadi and Tourani-Rad (2011).

The firm-level control variables have statistically significant individual influences of $1 \%$ and $5 \%$, respectively. The exception makes the degree of indebtedness that does not generate a statistically significant influence.

In line with previous findings (Panda, 2015), firm size is positively associated with the evolution of turnover as a result of their stronger market penetration force by effective trade strategies. Firm age negatively influences the growth rate of the entity, thus reflecting a de- 
crease in companies' elasticity to changes in the economic environment, at the same time as their maturation, which is in opposition to results reported by Megaravalli and Sampagnaro (2018) in the study realized on HGFs. The growth of labor productivity reflects the increase in employee efficiency, which offers the opportunity to develop commercial strategies that lead to increased sales.

The macroeconomic environment in which firms operate can influence the phenomenon analyzed through the quality of the specific business environment. In this respect, the direct link between economic growth and firm growth reflects the positive dependence relationship between the two variables, the results being similar to the findings of Krasniqi and Desai (2016). On the other hand, economic development negatively influences sales growth. These results can be explained by the equilibrium effect of markets, generated by the increase of

Table 5. Empirical results for the post-high-growth period (2010-2014)

\begin{tabular}{|c|c|c|c|}
\hline & Model 1 & Model 2 & Model 3 \\
\hline & OLS & $\mathrm{FE}$ & PCSE \\
\hline \multirow{2}{*}{ DAC } & $-0.2004^{* * *}$ & $-0.4110^{* * *}$ & $-0.2523^{* * *}$ \\
\hline & $(-0.044)$ & $(-0.0726)$ & $(-0.0387)$ \\
\hline \multirow{2}{*}{ NDAC } & -0.1066 & $-0.1648^{\star \star}$ & $-0.1231^{\star \star}$ \\
\hline & $(-0.0783)$ & $(-0.0733)$ & $(-0.0606)$ \\
\hline \multirow{2}{*}{ SIZE } & -0.0006 & $0.1963^{\star * *}$ & -0.0162 \\
\hline & $(-0.0121)$ & $(-0.0509)$ & $(-0.0123)$ \\
\hline \multirow{2}{*}{ AGE } & -0.1865 & 0.1856 & -0.1798 \\
\hline & $(-0.1266)$ & $(-0.4673)$ & $(-0.1329)$ \\
\hline \multirow{2}{*}{ LP } & $0.1295^{\star * *}$ & $0.5835^{\star * \star}$ & $0.1898^{\star * \star}$ \\
\hline & $(-0.0266)$ & $(-0.0535)$ & $(-0.0271)$ \\
\hline \multirow{2}{*}{$\mathrm{DR}$} & 0.002 & $0.1991^{*}$ & 0.0247 \\
\hline & $(-0.0768)$ & $(-0.1065)$ & $(-0.0687)$ \\
\hline \multirow{2}{*}{ ECGR } & $0.0419^{* * *}$ & $0.0352^{* * *}$ & $0.0430^{\star \star \star}$ \\
\hline & $(-0.0054)$ & $(-0.0064)$ & $(-0.0054)$ \\
\hline \multirow{2}{*}{ ECDEV } & $-0.0740^{* * *}$ & $-0.6811^{* * *}$ & $-0.1007^{* * *}$ \\
\hline & $(-0.0257)$ & $(-0.2085)$ & $(-0.0255)$ \\
\hline \multirow{2}{*}{ Constant } & -0.3988 & -3.3356 & $-0.5995^{\star}$ \\
\hline & $(-0.2871)$ & $(-2.2587)$ & $(-0.318)$ \\
\hline Time FE & Yes & Yes & Yes \\
\hline Industry FE & Yes & Yes & Yes \\
\hline Observations & 2668 & 2668 & 2668 \\
\hline R-squared & 0.1603 & 0.0901 & 0.1954 \\
\hline
\end{tabular}

Note: Robust standard errors are reported in brackets and account for clustering at the firm level. ${ }^{* *}$, ${ }^{*}$, and ${ }^{*}$ denote statistical significance at the $1 \%, 5 \%$, and $10 \%$ levels, respectively. 
national per capita incomes, as well as by the specialization of consumers, which can lead to a decrease in the growth rate of businesses.

The results are consistent in all three models used, the relationships remaining constant, by sign, magnitude, and degree of statistical significance.

The negative relationship between DAC and firm growth is confirmed also for the posthigh-growth period (2010-2014) (see Table 5), respectively the whole period (2006-2014) (see Table 6). However, there is an increased influence of DAC on firm growth over the high-growth period compared to the post-high-growth period. Thus, more intense use of accounting choices can be reflected in possible earnings management actions in order to achieve high-growth.

Table 6. Empirical results for the whole period (2006-2014)

\begin{tabular}{|c|c|c|c|}
\hline & Model 1 & Model 2 & Model 3 \\
\hline & OLS & $\mathrm{FE}$ & PCSE \\
\hline \multirow{2}{*}{ DAC } & $-0.2218^{\star * *}$ & $-0.3528^{* * *}$ & $-0.2689^{\star * *}$ \\
\hline & $(-0.0336)$ & $(-0.0423)$ & $(-0.0243)$ \\
\hline \multirow{2}{*}{ NDAC } & -0.0382 & -0.0418 & -0.0355 \\
\hline & $(-0.0545)$ & $(-0.0494)$ & $(-0.0375)$ \\
\hline \multirow{2}{*}{ SIZE } & $0.0236^{* *}$ & $0.1072^{\star * *}$ & 0.0026 \\
\hline & $(-0.0114)$ & $(-0.0392)$ & $(-0.0135)$ \\
\hline \multirow{2}{*}{ AGE } & $-0.5896^{* * *}$ & $-1.3977^{* * *}$ & $-0.6996^{* * *}$ \\
\hline & $(-0.0859)$ & $(-0.2144)$ & $(-0.0833)$ \\
\hline \multirow{2}{*}{ LP } & $0.0840^{* * *}$ & $0.4769^{* * *}$ & $0.1613^{* * *}$ \\
\hline & $(-0.0237)$ & $(-0.0505)$ & $(-0.0242)$ \\
\hline \multirow{2}{*}{$\mathrm{DR}$} & 0.0905 & 0.1281 & 0.0915 \\
\hline & $(-0.0603)$ & $(-0.0969)$ & $(-0.0656)$ \\
\hline \multirow{2}{*}{ ECGR } & $0.0196^{* * *}$ & $0.0261^{* * *}$ & $0.0195^{\star * *}$ \\
\hline & $(-0.0037)$ & $(-0.0046)$ & $(-0.0043)$ \\
\hline \multirow{2}{*}{ ECDEV } & $-0.1092^{\star * *}$ & $-0.8185^{\star * *}$ & $-0.1475^{\star * *}$ \\
\hline & $(-0.0231)$ & $(-0.1997)$ & $(-0.0226)$ \\
\hline \multirow{2}{*}{ Constant } & $0.7400^{\star * *}$ & 2.2392 & $0.6205^{* * *}$ \\
\hline & $(-0.2099)$ & $(-1.8714)$ & $(-0.2312)$ \\
\hline Time FE & Yes & Yes & Yes \\
\hline Industry FE & Yes & Yes & Yes \\
\hline Observations & 4467 & 4467 & 4467 \\
\hline R-squared & 0.212 & 0.1286 & 0.2267 \\
\hline
\end{tabular}

Note: Robust standard errors are reported in brackets and account for clustering at the firm level. ${ }^{* * *}$, ${ }^{*}$, and ${ }^{*}$ denote statistical significance at the $1 \%, 5 \%$, and $10 \%$ levels, respectively. 


\subsection{Robustness tests}

In order to test the validity of the results obtained at the level of the whole sample, two robustness check approaches have been employed. Due to the differences between the countries in the sample in terms of economic growth and development, but also in the EU accession, the initial sample is split into two subsamples, namely gazelles located in the EU member states (EU) and gazelles located in the rest of the countries (Non-EU). The disjunctive element was represented by the number of firm-level observations available and the EU membership.

The results of the robustness checks for both sub-samples are reported in Table 7 and

Table 7. Robustness checks - EU vs Non-EU (2006-2014)

\begin{tabular}{|c|c|c|c|c|c|c|}
\hline \multicolumn{7}{|c|}{ Dependent variable -Sales growth } \\
\hline & & $\mathrm{EU}$ & & & Non-EU & \\
\hline \multirow{2}{*}{$\begin{array}{c}\text { Independent } \\
\text { Variables }\end{array}$} & Model 1 & Model 2 & Model 3 & Model 1 & Model 2 & Model 3 \\
\hline & OLS & $\mathrm{FE}$ & PCSE & OLS & $\mathrm{FE}$ & PCSE \\
\hline \multirow{2}{*}{ DAC } & $-0.2296^{\star \star *}$ & $-0.4508^{\star * *}$ & $-0.3112^{\star * *}$ & $-0.2143^{\star \star *}$ & $-0.2908^{\star * *}$ & $-0.2379^{* * *}$ \\
\hline & $(-0.0489)$ & $(-0.0725)$ & $(-0.036)$ & $(-0.0447)$ & $(-0.0503)$ & $(-0.032)$ \\
\hline \multirow{2}{*}{ NDAC } & -0.0009 & -0.0254 & -0.0195 & -0.0674 & -0.0671 & -0.0568 \\
\hline & $(-0.0838)$ & $(-0.0751)$ & $(-0.0563)$ & $(-0.0715)$ & $(-0.0658)$ & $(-0.0507)$ \\
\hline \multirow{2}{*}{ SIZE } & $0.0243^{\star}$ & $0.2051^{\star \star \star}$ & 0.0138 & 0.0215 & 0.0632 & -0.0019 \\
\hline & $(-0.0147)$ & $(-0.0374)$ & $(-0.0134)$ & $(-0.0185)$ & $(-0.0618)$ & $(-0.0226)$ \\
\hline \multirow{2}{*}{ AGE } & $-0.4921^{\star \star \star}$ & $-0.9125^{\star * *}$ & $-0.5397^{\star * *}$ & $-0.6559^{\star \star \star}$ & $-1.6131^{\star * *}$ & $-0.7738^{\star * *}$ \\
\hline & $(-0.1015)$ & $(-0.2444)$ & $(-0.0982)$ & $(-0.1286)$ & $(-0.3098)$ & $(-0.1189)$ \\
\hline \multirow{2}{*}{ LP } & $0.1008^{\star * *}$ & $0.4145^{\star \star \star}$ & $0.1634^{\star * *}$ & $0.0765^{\star *}$ & $0.5441^{\star * *}$ & $0.1435^{\star * *}$ \\
\hline & $(-0.0318)$ & $(-0.058)$ & $(-0.0269)$ & $(-0.0349)$ & $(-0.0784)$ & $(-0.0352)$ \\
\hline \multirow{2}{*}{ DR } & 0.1007 & 0.0579 & 0.1109 & 0.1232 & 0.2487 & 0.1249 \\
\hline & $(-0.0883)$ & $(-0.1186)$ & $(-0.0905)$ & $(-0.0792)$ & $(-0.1593)$ & $(-0.0916)$ \\
\hline \multirow{2}{*}{ ECGR } & $0.0137^{\star *}$ & $0.0275^{\star \star \star}$ & $0.0138^{\star \star}$ & 0.0096 & 0.0065 & 0.0084 \\
\hline & $(-0.0062)$ & $(-0.0071)$ & $(-0.0066)$ & $(-0.0071)$ & $(-0.0105)$ & $(-0.0078)$ \\
\hline \multirow{2}{*}{ ECDEV } & $-0.1007^{\star \star}$ & $-1.7369^{* * *}$ & $-0.1433^{\star * *}$ & $-0.2519^{\star * \star}$ & -0.7862 & $-0.2888^{* * *}$ \\
\hline & $(-0.0407)$ & $(-0.2821)$ & $(-0.0407)$ & $(-0.0827)$ & $(-0.5841)$ & $(-0.0819)$ \\
\hline \multirow{2}{*}{ Constant } & 0.3411 & $9.9070^{\star * *}$ & 0.2084 & $2.2041^{\star * *}$ & 1.9483 & $2.2346^{* * *}$ \\
\hline & $(-0.3978)$ & $(-2.6031)$ & $(-0.4084)$ & $(-0.6635)$ & $(-4.85)$ & $(-0.7001)$ \\
\hline Time FE & Yes & Yes & Yes & Yes & Yes & Yes \\
\hline Industry FE & Yes & Yes & Yes & Yes & Yes & Yes \\
\hline Observations & 2560 & 2560 & 2560 & 1907 & 1907 & 1907 \\
\hline R-squared & 0.2093 & 0.079 & 0.2349 & 0.2206 & 0.1269 & 0.2286 \\
\hline
\end{tabular}

Note: Robust standard errors are reported in brackets and account for clustering at the firm level. ${ }^{\star * *}$, ${ }^{*}$, and ${ }^{*}$ denote statistical significance at the $1 \%, 5 \%$, and $10 \%$ levels, respectively. 


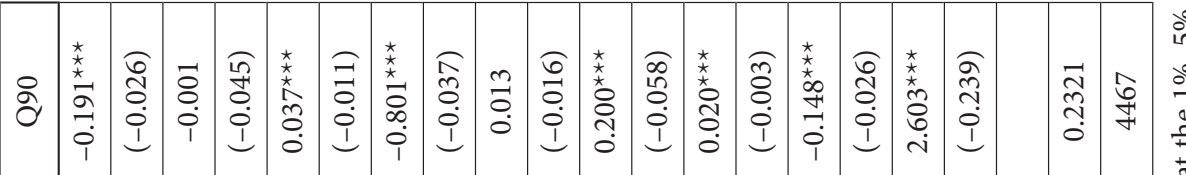

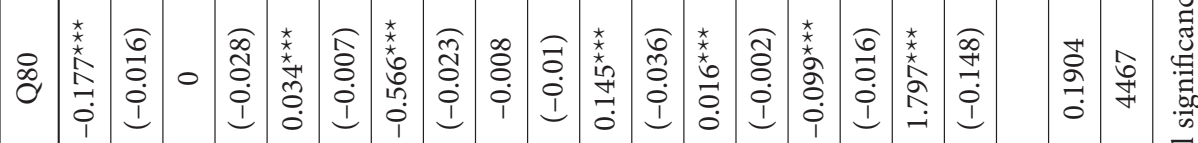

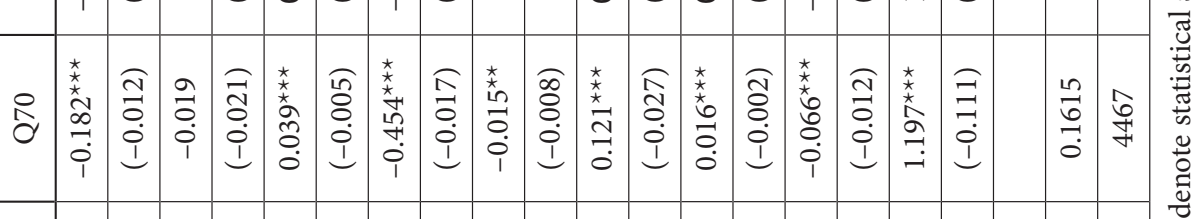

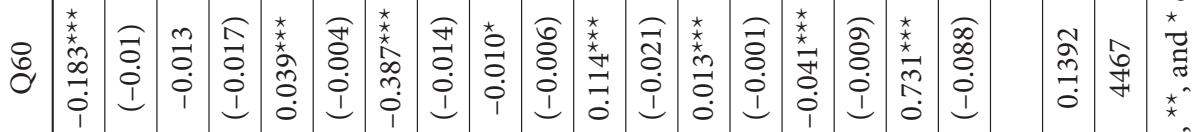

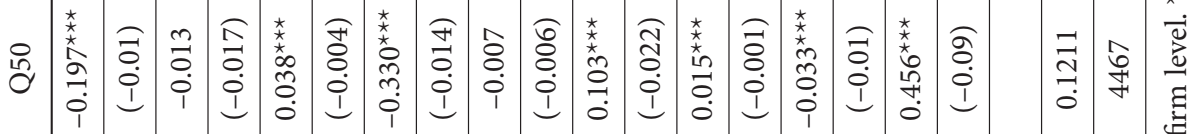

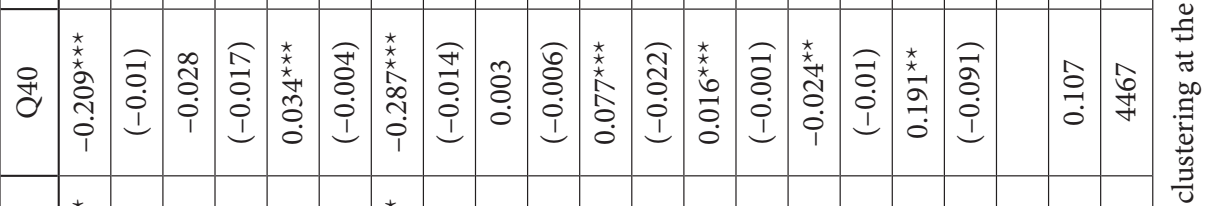

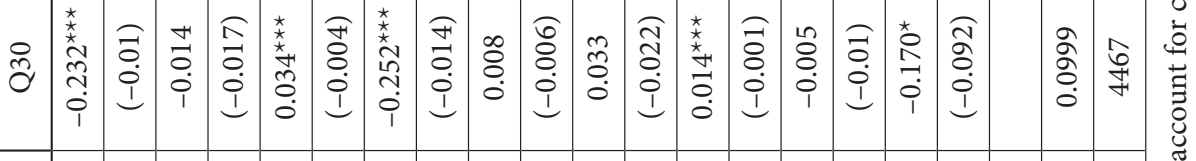

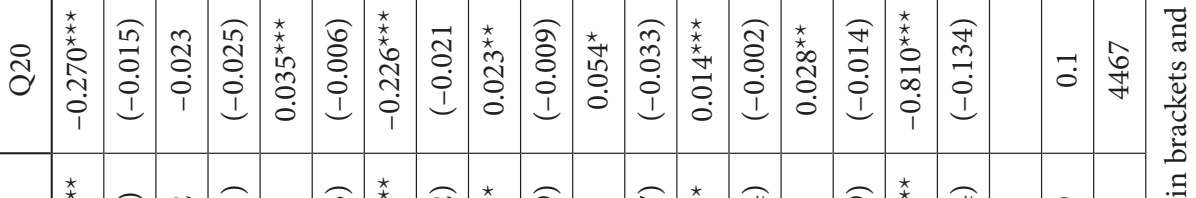

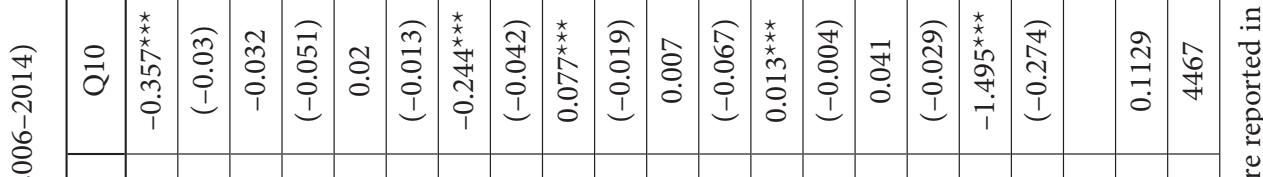

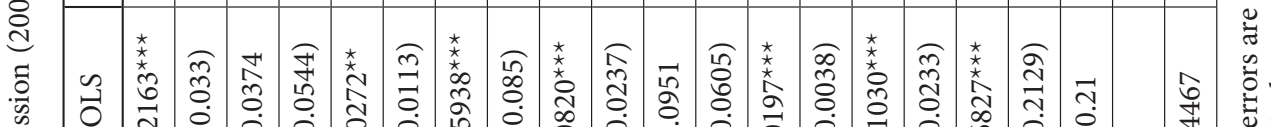

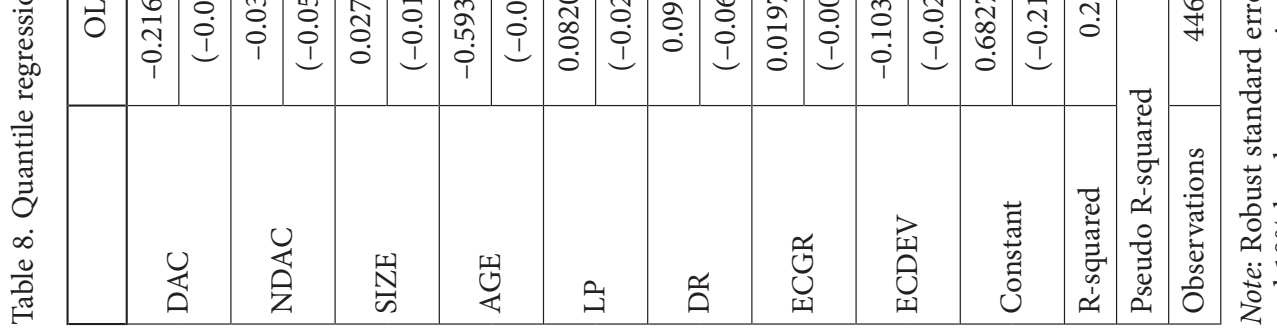


confirm the negative relationship between discretionary accruals and firm growth. It is worth to observe that, although the accounting rules that substantiates the processed financial information present particularities in each country, the magnitude of the DAC is interpreted similarly, respectively as a factor with negative influence on firm growth, which can reflect actions of manipulation of the results.

A second way of testing the robustness of the preliminary results consists in the employment of panel quantile regression. The analysis aimed to identify the causality relationships on the interval of sales growth (from $10 \%$ to $90 \%$ quantile) as well as dimensional deviations of the partial influences of the explanatory variables according to the growth rate of the firm. Table 8 presents the quantile regression results.

The results confirm once again the robustness of the previous results in all the sequential models tested, the causal relationship maintaining its characteristics and significance. From a quantitative perspective, there is an increased contribution of the DAC to the decrease in firm growth within the first three quantiles, all the regression coefficients attached to the discretionary accruals $(-0.232$ to -0.357$)$ exceed the value recorded for the whole sample $(-0.2163)$. In the same sense, but with a lower intensity $(-0.177$ to -0.209$)$ than the one recorded at the level of the total sample, the DAC influences the firm growth in the case of entities whose growth rates are in the last six quantiles $\mathrm{q} 40$ to $\mathrm{q} 90$. This confirms once again the dependence of the growth rate of sales on the magnitude of the DAC, respectively their role in signaling the future performance of the firm.

Validating the results of the study by using a time horizon that includes two business cycles (economic growth and downturn), respectively confirming the robustness of the analyzes by testing the models at the level of quantiles, offer greater sustainability of the conclusions.

\section{Conclusions}

Although the quality of accounting information is a widely discussed subject in the specialized literature, the relationship between this attribute and firm growth is still insufficiently researched. The qualitative level of financial information reported by firms can influence their growth, both directly through the effect on the decisions of different users and indirectly through the interpretation of some indicators developed on inaccurate or less relevant data. For this reason, the paper aims to evaluate the effect of discretionary accruals (as an exponent of managerial decisions on accounting choice) on firm growth. Due to the increased growth rate and to the additional motivations they can have in earnings management (i.e., to maintain the target level of performance), the study was conducted on a sample of young HGFs (so-called gazelles), both over the high-growth (2006-2009) and over the post-high-growth period (2010-2014). Another feature of the sample is that the firms are SMEs from emerging economies from CESEE countries, which have been scarcely researched so far. Futhermore, the period of analysis (2006-2019) allow us to assess the impact of economic growth and financial crisis on firm growth.

The empirical findings show the discretionary accruals are negatively influencing firm growth, which reflects their use as a tool for earnings management through accounting choice. The negative relationship is more pronounced over the high-growth period (2006- 
2009) and it hampers future growth. The effects are also confirmed by the results of the quantile regression employed in the whole period, the magnitude of the relationship being higher in the case of low-growth firms. The relationship has been validated through three econometric specifications, its sense and significance remaining constant. The robustness of our findings is tested by employing two sub-samples (gazelles from the EU member states and those from other countries) and by using several estimation techniques. The role of nondiscretionary accruals on firm growth is insignificant due to their strict rules of recognition.

The paper contributes to the extant literature by providing evidence of the effect of discretionary accruals on firm growth using a sample of gazelles located in emerging markets economies. The study analyzes the phenomenon on a cross-country sample of gazelles, including the effect of the macroeconomic environment through specific variables (economic growth and economic development). Also, the current paper extends previous studies in terms of the methodology employed for testing the linkage between discretionary accruals and firm growth by using the quantile regression.

The accruals' dimension, as an exponent of the differences between cash accounting principles and accrual accounting, and in particular the magnitude of discretionary accruals, is interpreted predominantly as a tool for earnings management. In terms of practical implications, the current study lends support for the need for more detailed information provided by firms on the origin of the accruals, as well as for the use in the performance analysis of some indicators that eliminate the influence of accruals, such as cash flow based ratios.

This study is not without limitations. The first research limit consists of focusing the study only on gazelles located in emerging countries from CESEE for the period 2006-2014. It is necessary to extend the analysis to other emerging countries, different types of firms (family firms, listed firms or multinational firms) and more recent data. Secondly, it is necessary to complete the set of control variables with some specific corporate governance variables which were not available in our databases, such as the ownership structure or the management and internal control system. Thirdly, the inferences derived from our study are limited by the data on which the results are based. Future research directions may involve the removal of these restrictions and the inclusion as a comparative dimension of the listed firms.

\section{Author contributions}

Both authors contributed equally to the paper, namely to review the literature, collect data, apply research methods and interpret the results.

\section{References}

Abernathy, J. L., Beyer, B., \& Rapley, E. T. (2014). Earnings management constraints and classification shifting. Journal of Business Finance and Accounting, 41(5-6), 600-626. https://doi.org/10.1111/jbfa.12076

Anton, S. G. (2019). Leverage and firm growth: An empirical investigation of gazelles from emerging Europe. International Entrepreneurship and Management Journal, 15(1), 209-232. https://doi.org/10.1007/s11365-018-0524-5 
Arun, T. G., Almahrog, Y. E., \& Aribi, Z. A. (2015). Female directors and earnings management: Evidence from UK companies. International Review of Financial Analysis, 39, 137-146. https://doi.org/10.1016/j.irfa.2015.03.002

Ben Amar, A., Ben Salah, O., \& Jarboui, A. (2018). Do discretionary accruals affect firms' corporate dividend policy? Evidence from France. Journal of Financial Reporting and Accounting, 16(2), 333-347. https://doi.org/10.1108/JFRA-03-2017-0020

Beuselinck, C., Deloof, M., \& Manigart, S. (2009). Private equity involvement and earnings quality. Journal of Business Finance \& Accounting, 36(5-6), 587-615. https://doi.org/10.1111/j.1468-5957.2009.02147.x

Campa, D. (2015). The impact of SME's pre-bankruptcy financial distress on earnings management tools. International Review of Financial Analysis, 42, 222-234. https://doi.org/10.1016/j.irfa.2015.07.004

Capalbo, F., Frino, A., Mollica, V., \& Palumbo, R. (2014). Accrual-based earnings management in state owned companies: Implications for transnational accounting regulation. Accounting, Auditing \& Accountability Journal, 27(6), 1026-1040. https://doi.org/10.1108/AAAJ-06-2014-1744

Chen, A., \& Gong, J. J. (2019). Accounting comparability, financial reporting quality, and the pricing of accruals. Advances in Accounting, 45, 100415. https://doi.org/10.1016/j.adiac.2019.03.003

Chen, F., Hope, O. K., Li, Q., \& Wang, X. (2011). Financial reporting quality and investment efficiency of private firms in emerging markets. The Accounting Review, 86(4), 1255-1288. https://doi.org/10.2308/accr-10040

Collins, D. W., Pungaliya, R. S., \& Vijh, A. M. (2016). The effects of firm growth and model specification choices on tests of earnings management in quarterly settings. The Accounting Review, 92(2), 69-100. https://doi.org/10.2308/accr-51551

Darmawan, I. P. E., Sutrisno, T., \& Mardiati, E. (2019). Accrual earnings management and real earnings management: Increase or destroy firm value? International Journal of Multicultural and Multireligious Understanding, 6(2), 8-19. https://doi.org/10.18415/ijmmu.v6i2.551

Datta, S., Iskandar-Datta, M., \& Singh, V. (2013). Product market power, industry structure, and corporate earnings management. Journal of Banking \& Finance, 37(8), 3273-3285. https://doi.org/10.1016/j.jbankfin.2013.03.012

Davidsson, P., \& Wiklund, J. (2006). Conceptual and empirical challenges in the study of firm growth. In P. Davidsson, F. Delmar, \& J. Wiklund (Eds), Entrepreneurship and the Growth of Firms (pp. 3961). Edward Elgar Publishing. https://doi.org/10.4337/9781781009949.00010

Dechow, P. M., Hutton, A. P., Kim, J. H., \& Sloan, R. G. (2012). Detecting earnings management: A new approach. Journal of Accounting Research, 50(2), 275-334. https://doi.org/10.1111/j.1475-679X.2012.00449.x

Dechow, P. M., Larson, C. R., \& Resutek, R. J. (2019). Discretion lost? Accrual heterogeneity and implications for accrual quality inferences. Retrieved 8 March, 2019 from SSRN: https://ssrn.com/ abstract $=3223968$

Doukakis, L. C. (2014). The effect of mandatory IFRS adoption on real and accrual-based earnings management activities. Journal of Accounting and Public Policy, 33(6), 551-572.

https://doi.org/10.1016/j.jaccpubpol.2014.08.006

Eurostat-OECD. (2007). Eurostat-OECD manual on business demography statistics. European Commission - OECD, Paris.

Filip, A., \& Raffournier, B. (2014). Financial crisis and earnings management: The European evidence. The International Journal of Accounting, 49(4), 455-478. https://doi.org/10.1016/j.intacc.2014.10.004

Filip, A., Labelle, R., \& Rousseau, S. (2015). Legal regime and financial reporting quality. Contemporary Accounting Research, 32(1), 280-307. https://doi.org/10.1111/1911-3846.12071 
Fischer, M., \& Rosenzweig, K. (1995). Attitudes of students and accounting practitioners concerning the ethical acceptability of earnings management. Journal of Business Ethics, 14(6), 433-444. https://doi.org/10.1007/BF00872085

Francis, J., LaFond, R., Olsson, P., \& Schipper, K. (2005). The market pricing of accruals quality. Journal of Accounting and Economics, 39(2), 295-327. https://doi.org/10.1016/j.jacceco.2004.06.003

Gao, J., Cong, L. M., \& Evans, J. (2015). Earnings management, IPO underpricing, and post-issue stock performance of Chinese SMEs. The Chinese Economy, 48(5), 351-371. https://doi.org/10.1080/10971475.2015.1067085

Gavious, I., Segev, E., \& Yosef, R. (2012). Female directors and earnings management in high-technology firms. Pacific Accounting Review, 24(1), 4-32. https://doi.org/10.1108/01140581211221533

Ge, W., \& Kim, J. B. (2014). Real earnings management and the cost of new corporate bonds. Journal of Business Research, 67(4), 641-647. https://doi.org/10.1016/j.jbusres.2013.01.021

Habib, A. (2013). Financial distress, earnings management and market pricing of accruals during the global financial crisis. Managerial Finance, 39(2), 155-180. https://doi.org/10.1108/03074351311294007

Haga, J., Höglund, H., \& Sundvik, D. (2018). Stock market listing status and real earnings management. Journal of Accounting and Public Policy, 37(5), 420-435. https://doi.org/10.1016/j.jaccpubpol.2018.09.002

Healy, P. M., \& Wahlen, J. M. (1999). Review of the earnings management literature and its implications for standard setting. Accounting Horizons, 13, 365-383. https://doi.org/10.2308/acch.1999.13.4.365

Heese, J. (2018). The role of overbilling in hospitals' earnings management decisions. European Accounting Review, 27(5), 875-900. https://doi.org/10.1080/09638180.2017.1383168

Hsiao, C. (2003). Analysis of panel data ( $2^{\text {nd }}$ ed.). Cambridge University Press. https://doi.org/10.1017/CBO9780511754203

International Monetary Fund. (2020). The financial sector in the 2020s: Building a more inclusive system in the new decade. https://www.imf.org/en/News/Articles/2020/01/17/sp01172019-the-financialsector-in-the-2020s\#_edn20

Jenkins, D. S., \& Velury, U. K. (2012). Auditor tenure and the pricing of discretionary accruals in the post-SOX era. Accounting and the Public Interest, 12(1), 1-15. https://doi.org/10.2308/apin-10204

Jones, J. J. (1991). Earnings management during import relief investigations. Journal of Accounting Research, 29(2), 193-228. https://doi.org/10.2307/2491047

Karampinis, N. I., \& Hevas, D. L. (2013). Effects of IFRS adoption on tax-induced incentives for financial earnings management: Evidence from Greece. The International Journal of Accounting, 48(2), 218-247. https://doi.org/10.1016/j.intacc.2013.04.003

Koenker, R., \& Bassett, G. (1978). Regression quantiles. Econometrica, 46(1), 33-50. https://doi.org/10.2307/1913643

Koerniadi, H., \& Tourani-Rad, A. (2011). The role of accruals as a signal in earnings and dividend announcements: New Zealand evidence. Journal of Applied Accounting Research, 12(2), 108-122. https://doi.org/10.1108/09675421111160682

Krasniqi, B. A., \& Desai, S. (2016). Institutional drivers of high-growth firms: country-level evidence from 26 transition countries. Small Business Economics, 47(4), 1075-1094. https://doi.org/10.1007/s11187-016-9736-7

Kuo, J. M., Ning, L., \& Song, X. (2014). The real and accrual-based earnings management behaviors: Evidence from the split share structure reform in China. The International Journal of Accounting, 49(1), 101-136. https://doi.org/10.1016/j.intacc.2014.01.001

Lehmann, N. (2016). The role of corporate governance in shaping accruals manipulation prior to acquisitions. Accounting and Business Research, 46(4), 327-364.

https://doi.org/10.1080/00014788.2015.1116969 
Lo, K., Ramos, F., \& Rogo, R. (2017). Earnings management and annual report readability. Journal of Accounting and Economics, 63(1), 1-25. https://doi.org/10.1016/j.jacceco.2016.09.002

Megaravalli, A. V., \& Sampagnaro, G. (2018). Predicting the growth of high-growth SMEs: Evidence from family business firms. Journal of Family Business Management, 9(1), 98-109. https://doi.org/10.1108/JFBM-09-2017-0029

Miroshnychenko, I., Bozzi, S., \& Barontini, R. (2018). Firm growth and legal environment. Economic notes: Review of banking. Finance and Monetary Economics, 48(1), 12116. https://doi.org/10.1111/ecno.12116

Momente, F., Reggiani, F., \& Richardson, S. (2015). Accruals and future performance: Can it be attributed to risk? Review of Accounting Studies, 20(4), 1297-1333. https://doi.org/10.1007/s11142-015-9319-x

Omar, N., Rahman, R. A., Danbatta, B. L., \& Sulaiman, S. (2014). Management disclosure and earnings management practices in reducing the implication risk. Procedia - Social and Behavioral Sciences, 145, 88-96. https://doi.org/10.1016/j.sbspro.2014.06.014

Owens, E. L., Wu, J. S., \& Zimmerman, J. (2016). Idiosyncratic shocks to firm underlying economics and abnormal accruals. The Accounting Review, 92(2), 183-219. https://doi.org/10.2308/accr-51523

Panda, D. (2015). Growth determinants in small firms: Drawing evidence from the Indian agro-industry. International Journal of Commerce and Management, 25(1), 52-66. https://doi.org/10.1108/IJCoMA-12-2012-0080

Pelucio-Grecco, M. C., Geron, C. M. S., Grecco, G. B., \& Lima, J. P. C. (2014). The effect of IFRS on earnings management in Brazilian non-financial public companies. Emerging Markets Review, 21, 42-66. https://doi.org/10.1016/j.ememar.2014.07.001

Perotti, P., \& Wagenhofer, A. (2014). Earnings quality measures and excess return. Journal of Business Finance \& Accounting, 41(5-6), 545-571. https://doi.org/10.1111/jbfa.12071

Pham, H. Y., Chung, R. Y. M., Roca, E., \& Bao, B. H. (2017). Discretionary accruals: signalling or earnings management in Australia? Accounting \& Finance, 59(2), 1383-1413. https://doi.org/10.1111/acfi.12275

Rahaman, M. (2011). Access to financing and firm growth. Journal of Banking and Finance, 35(3), 709-723. https://doi.org/10.1016/j.jbankfin.2010.09.005

Robin, A., \& Wu, Q. (2015). Firm growth and the pricing of discretionary accruals. Review of Quantitative Finance and Accounting, 45(3), 561-590. https://doi.org/10.1007/s11156-014-0447-3

Rodrigues, R. M. R. C., Melo, C. L. L. D., \& Paulo, E. (2019). Earnings management and quarterly discretionary accruals level in the Brazilian stock market. Brazilian Business Review, 16(3), 297-314. https://doi.org/10.15728/bbr.2019.16.3.6

Sial, M., Zheng, C., Khuong, N., Khan, T., \& Usman, M. (2018). Does Firm performance influence corporate social responsibility reporting of Chinese listed companies? Sustainability, 10(7), 2217. https://doi.org/10.3390/su10072217

Sun, N., Salama, A., Hussainey, K., \& Habbash, M. (2010). Corporate environmental disclosure, corporate governance and earnings management. Managerial Auditing Journal, 25(7), 679-700. https://doi.org/10.1108/02686901011061351

Szczesny, A., \& Valentincic, A. (2013). Asset write-offs in private firms - The case of German SMEs. Journal of Business Finance \& Accounting, 40(3-4), 285-317. https://doi.org/10.1111/jbfa.12017

Teoh, S. H., Welch, I., \& Wong, T. J. (1998). Earnings management and the underperformance of seasoned equity offerings. Journal of Financial Economics, 50(1), 63-99. https://doi.org/10.1016/S0304-405X(98)00032-4

Tsipouridou, M., \& Spathis, C. (2012). Earnings management and the role of auditors in an unusual IFRS context: The case of Greece. Journal of International Accounting, Auditing and Taxation, 21(1), 62-78. https://doi.org/10.1016/j.intaccaudtax.2012.01.005 
Vafeas, N., Trigeorgis, L., \& Georgiou, X. (1998). The usefulness of earnings in explaining stock returns in an emerging market: The case of Cyprus. European Accounting Review, 7(1), 105-124. https://doi.org/10.1080/096381898336600

Vladu, A. B., Amat, O., \& Cuzdriorean, D. D. (2017). Truthfulness in accounting: how to discriminate accounting manipulators from non-manipulators. Journal of Business Ethics, 140(4), 633-648. https://doi.org/10.1007/s10551-016-3048-3

Walker, M. (2013). How far can we trust earnings numbers? What research tells us about earnings management. Accounting and Business Research, 43(4), 445-481. https://doi.org/10.1080/00014788.2013.785823

Wilson, M., \& Wang, L. W. (2010). Earnings management following chief executive officer changes: the effect of contemporaneous chairperson and chief financial officer appointments. Accounting \& Finance, 50(2), 447-480. https://doi.org/10.1111/j.1467-629X.2009.00324.x

World Bank. (2016). World development indicators. Resource document. http://data.worldbank.org/data-catalog/world-development-indicators

Zang, A. Y. (2012). Evidence on the trade-off between real activities manipulation and accrual-based earnings management. The Accounting Review, 87, 675-703. https://doi.org/10.2308/accr-10196

Zéghal, D., Chtourou, S., \& Sellami, Y. M. (2011). An analysis of the effect of mandatory adoption of IAS/IFRS on earnings management. Journal of International Accounting, Auditing and Taxation, 20(2), 61-72. https://doi.org/10.1016/j.intaccaudtax.2011.06.001 